Article

\title{
Diversity Patterns of Late Jurassic Chondrichthyans: New Insights from a Historically Collected Hybodontiform Tooth Assemblage from Poland
}

\author{
Sebastian Stumpf ${ }^{1, *(\mathbb{D})}$, Stefan Meng ${ }^{2}$ and Jürgen Kriwet ${ }^{1} \mathbb{D}$ \\ 1 Department of Palaeontology, University of Vienna, Geozentrum, Althanstraße 14, 1090 Vienna, Austria; \\ juergen.kriwet@univie.ac.at \\ 2 Institute of Geography and Geology, University of Greifswald, Friedrich-Ludwig-Jahn Straße 17a, \\ 17489 Greifswald, Germany; stefan.meng@uni-greifswald.de \\ * Correspondence: sebastian.stumpf@univie.ac.at
}

Citation: Stumpf, S.; Meng, S.; Kriwet, J. Diversity Patterns of Late Jurassic Chondrichthyans: New Insights from a Historically Collected Hybodontiform Tooth Assemblage from Poland. Diversity 2022, 14, 85. https://doi.org/10.3390/d14020085

Academic Editors: Michael Wink and Eric Buffetaut

Received: 23 November 2021

Accepted: 23 January 2022

Published: 26 January 2022

Publisher's Note: MDPI stays neutral with regard to jurisdictional claims in published maps and institutional affiliations.

Copyright: (C) 2022 by the authors. Licensee MDPI, Basel, Switzerland. This article is an open access article distributed under the terms and conditions of the Creative Commons Attribution (CC BY) license (https:// creativecommons.org/licenses/by/ $4.0 /)$.

\begin{abstract}
Here, we provide a detailed taxonomic reassessment of a historically collected chondrichthyan dental assemblage from the lower Kimmeridgian of Czarnogłowy in north-western Poland and discuss its significance for better understanding hybodontiform diversity patterns prior to their post-Jurassic decline in fully marine environments. In spite of its low taxonomic diversity, consisting of four large-toothed taxa (viz., Strophodus udulfensis, Asteracanthus ornatissimus, Planohybodus sp. and cf. Meristodonoides sp.), this assemblage is remarkable in that there are only very few Mesozoic hybodontiform assemblages with more large-toothed genera or even species. Comparisons with other European Late Jurassic hybodontiform-bearing localities demonstrate fairly homogenous distribution patterns characterized by large-bodied epipelagic forms of high dispersal ability. This is in stark contrast to post-Jurassic hybodontiform associations, which are dominated by smaller species that were predominantly bound to marginal marine and continental waters, suggesting a major reorganization of chondrichthyan communities during the Early Cretaceous.
\end{abstract}

Keywords: Chondrichthyes; Hybodontiformes; diversity; biogeography; Kimmeridgian; Late Jurassic; Poland

\section{Introduction}

The Late Jurassic marks a critical time interval in the history of life leading to dramatic episodes of global environmental perturbation at the Jurassic/Cretaceous $(\mathrm{J} / \mathrm{K})$ boundary [1], which seemingly affected vertebrate communities in both the terrestrial and marine realms (e.g., [2-7]). Among marine vertebrates, hybodontiform shark-like chondrichthyans, which form a supposed sister group to the elasmobranch crown encompassing modern sharks, skates and rays (=Neoselachii sensu [8]), witnessed a diversity decline in marine ecosystems from the Early Cretaceous onwards, before they predominately occurred in marginal marine and continental environments, where they flourished and diversified until they finally vanished at the end of the Cretaceous (e.g., [9-15]). However, the controlling factors driving the diversity dynamics of post-Jurassic hybodontiforms remain unresolved.

Hybodontiforms, whose fossil record is dominated by isolated dental remains (see [16] for overview), have been recorded from various European Late Jurassic localities so far (e.g., [17-31]), with rather rare occurrences from Asia [32-35], Africa [36,37] and South America [38-40]. However, even after more than two centuries of extensive research, our knowledge of Late Jurassic hybodontiforms is still insufficient, such that their diversity and distribution patterns remain ambiguous and poorly understood.

The intention of this study is (1) to provide a detailed taxonomic reassessment of a historically collected hybodontiform dental assemblage from the lower Kimmeridgian of Czarnogłowy in north-western Poland and (2) to discuss its significance in terms of 
ecology and biogeography for better understanding Mesozoic chondrichthyan life prior to the major environmental perturbations at the $\mathrm{J} / \mathrm{K}$ boundary.

\section{Materials and Methods}

\subsection{Fossil Material in This Study}

Although numerous Late Jurassic marine vertebrate-bearing localities have been reported from Poland since the 19th century (e.g., [19,41-48]), chondrichthyan remains are rare, originating from a few localities so far $[19,41,42,49,50]$.

The fossil chondrichthyan material that forms the focus of the present study is housed at the Institute of Geography and Geology, University of Greifswald, Germany, where it is catalogued under the repository numbers GG 303/1 to 303/94. The fossil material comprises isolated hybodontiform teeth that were originally collected during the first half of the 20th century from the now abandoned open-pit limestone quarry of Czarnogłowy (called Zarnglaff in the pre-1945 literature) in north-western Poland (Figure 1). Although first mentioned in 1784 by Brüggemann [51], it was not until the beginning of the 20th century that commercial mining started in Czarnogłowy. Mining activities continued until the 1970s, since when the Czarnogłowy quarry has been dormant and largely inaccessible due to flooding.

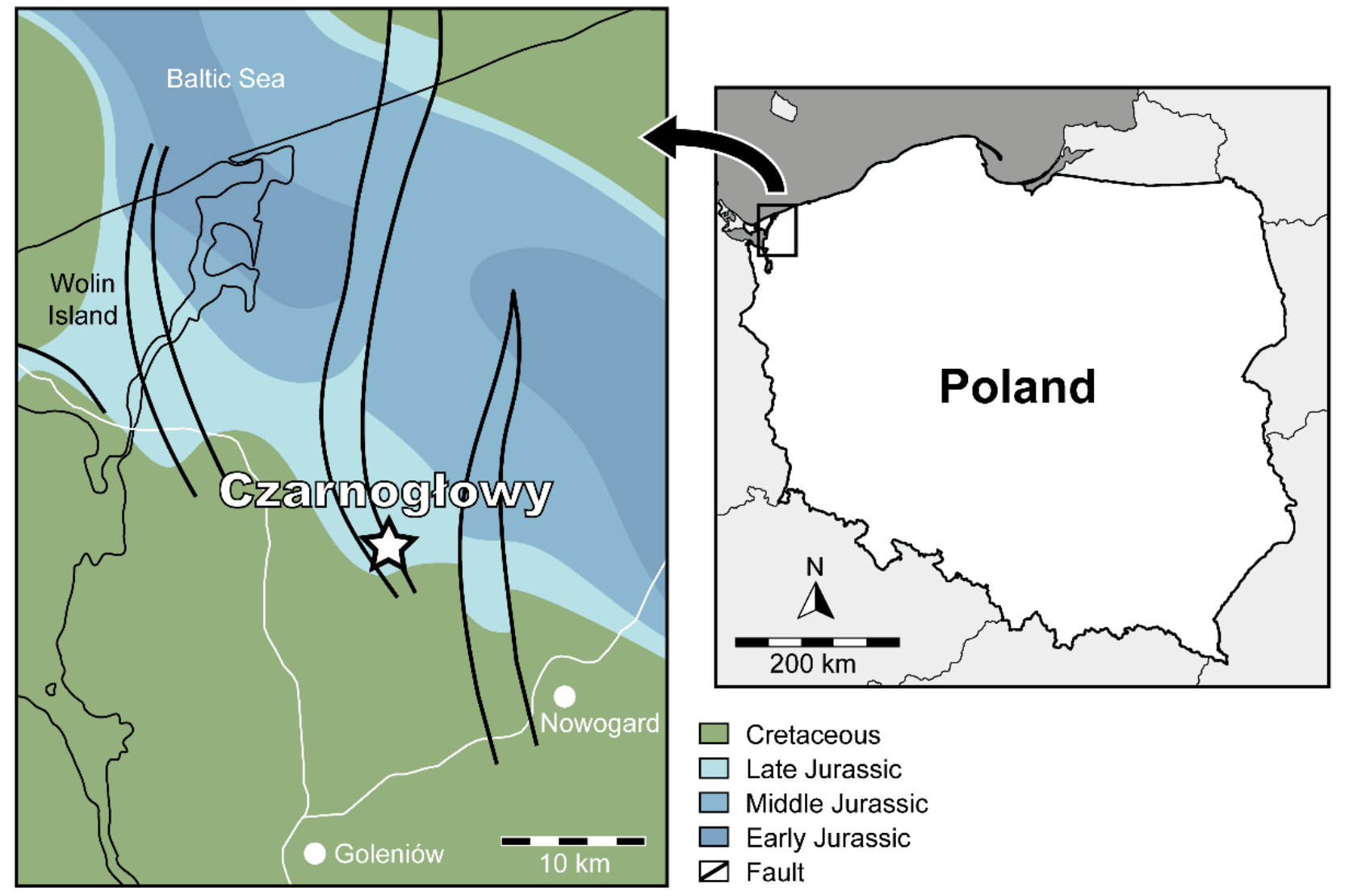

Figure 1. Location maps (geological map without Cenozoic cover; modified from [52]).

Belonging to the Mid-Polish Swell, which represents a NW-SE trending inverted anticlinal structure, the Late Jurassic sedimentary succession once accessible in the Czarnogłowy quarry ranges stratigraphically from the late Oxfordian to the early Tithonian, with a thickness of about $50 \mathrm{~m}$ [53-56]. According to Schmidt [53] and Richter [54], the hybodontiform material described herein originally derived from a two-to-three-meters-thick sequence of sandy, oolitic marlstone with occasional layers of wood remains. This interval, which is indicative of a warm, wave-agitated shallow-marine depositional environment, has also 
yielded fragmentary remains of actinopterygians and marine reptiles (e.g., [44,49,53,54]) and is dated to the early Kimmeridgian based on ammonite evidence $[55,56]$.

The historically collected hybodontiform assemblage presented herein was described in an unpublished thesis by Hoffmann [49], but the taxonomic identification by this author (see also [57] for brief summary) is challenged by recent advances in hybodontiform taxonomy. In addition, Hoffmann [49] also described rare dental remains of modern sharks retrieved from boulders collected around the abandoned Czarnogłowy quarry. However, while adding to the known taxonomic diversity of fossil chondrichthyans from Czarnogłowy, the precise stratigraphic position of this material within the Late Jurassic sedimentary succession once accessible in the Czarnogłowy quarry remains unknown.

\subsection{Methods}

All photographs presented in the text were obtained using a Nikon D5300 DSLR camera equipped with an AF-S DX Micro NIKKOR $40 \mathrm{~mm} \mathrm{f} / 2.8 \mathrm{G}$ lens. All photographs were rendered utilizing Adobe Photoshop CC 2021 and the accompanying figures were created using Adobe Illustrator CC 2021.

Descriptive tooth terminology used in this study largely follows that of Cappetta [16], whereas higher systematic relationships correspond to those of Maisey [58] and Rees and Underwood [59], although we acknowledge that currently available phylogenetic hypotheses for hybodontiforms are unsatisfactory [30,31].

\section{Results}

\subsection{Systematic Palaeontology}

Chondrichthyes Huxley, 1880 [60]

Elasmobranchii Bonaparte, 1838 [61]

Hybodontiformes Maisey, 1975 [62]

Hybodontidae Owen, 1846 [63]

Hybodontinae Owen, 1846 [63]

Planohybodus Rees and Underwood, 2008 [59]

Type species: Planohybodus peterboroughensis Rees and Underwood, 2008 [59]

Planohybodus sp.

Figure 2a-1.

\subsubsection{Material}

Sixteen incomplete teeth (GG303/1-16).

\subsubsection{Description}

The teeth are represented by partially preserved crowns forming a high and rather wide, somewhat labio-lingually flattened main cusp with well-developed cutting edges and a flattened labial crown face. The cusps have an oval cross-section (Figure 2g) and are slightly inclined distally and straight to somewhat sigmoid in mesio-distal view (Figure $2 \mathrm{~b}, \mathrm{e}$ ). Partially preserved lateral cusplets are present in two teeth (Figure $2 \mathrm{~h}-\mathrm{l}$ ), indicating that the main cusp was flanked by at least one pair of small lateral cusplets. The ornamentation consists of moderately well-developed vertical folds covering the lower parts of the labial (Figure 2a,d,h,k) and lingual crown faces, plus short, isolated folds occurring on the higher parts of the crown (Figure $2 \mathrm{c}, \mathrm{f}, \mathrm{j}, 1$ ). 


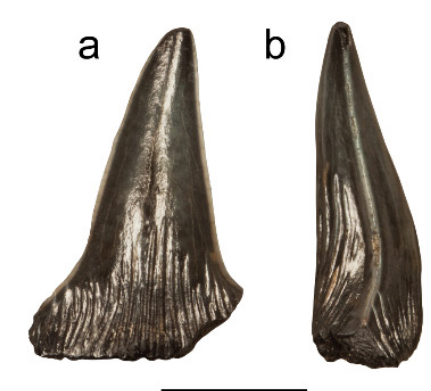

$5 \mathrm{~mm}$
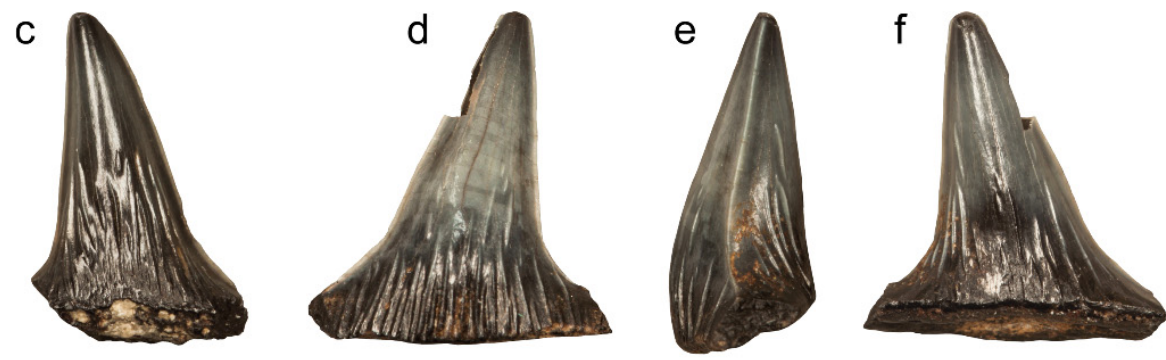

$5 \mathrm{~mm}$
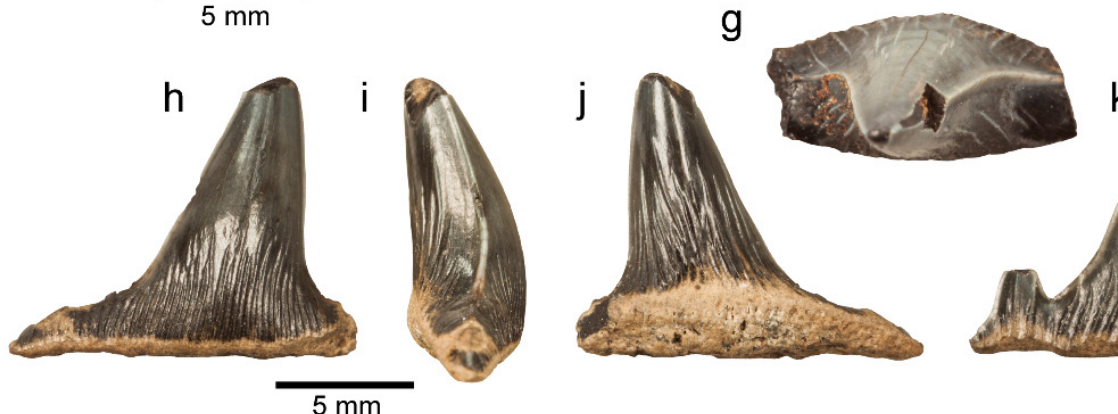

$k$ I
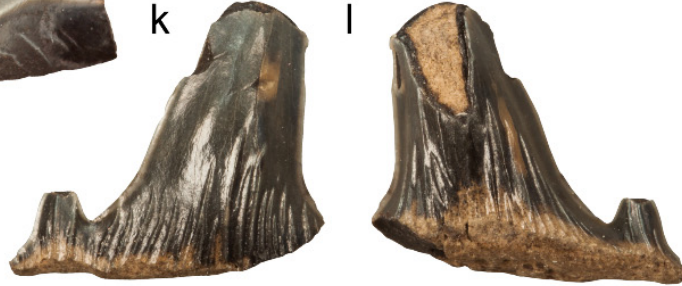

$5 \mathrm{~mm}$
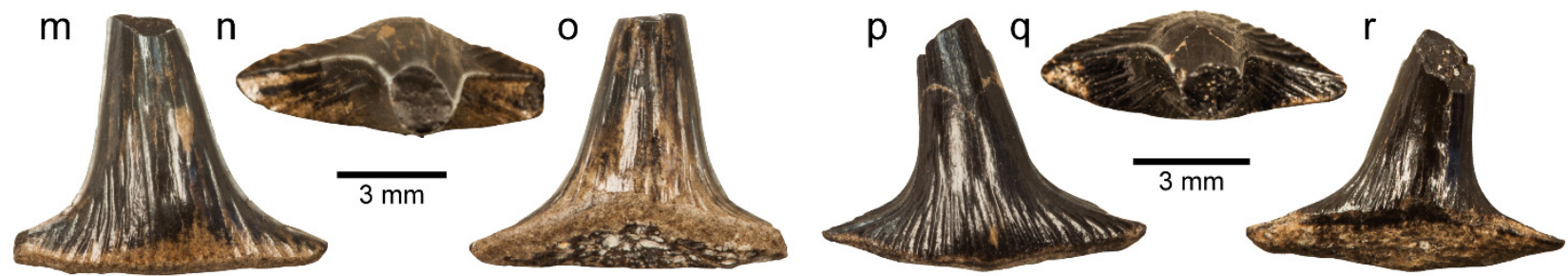

Figure 2. Historically collected hybodontiform teeth from the lower Kimmeridgian of Czarnogłowy, Poland. (a-1) Planohybodus sp., GG 303/1 in (a) labial, (b) mesial and (c) lingual view; GG 303/2 in (d) labial, (e) distal, (f) lingual and (g) apical view; GG GG303/3 in (h) labial, (i) mesial and (j) lingual aspect; GG 303/4 in (k) labial and (1) lingual view. (m-r) cf. Meristodonoides sp., GG 303/17 in (m) labial, (n) apical and (o) lingual aspect; GG 303/18 in (p) labial, (q) occlusal and (r) lingual view.

\subsubsection{Remarks}

The above-described teeth (plus those referred to below as cf. Meristodonoides sp.) were tentatively assigned by Hoffmann [49] to Hybodus sp. 1 and Hybodus sp. 2, respectively. Although generally accepted to form a highly polyphyletic assemblage encompassing numerous unrelated species characterized by very similar tooth morphologies (e.g., [30,59,64-66]), the taxonomic content of Hybodus Agassiz, 1837 [67] has become better understood in recent decades, which has led to the recognition of new genera such as Planohybodus Rees and Underwood, 2008 [59], Secarodus Rees and Underwood, 2008 [59], Meristodonoides Underwood and Cumbaa, 2010 [68] and Crassodus Maisch and Matzke, 2016 [66], as well as Durnonovariaodus Stumpf et al., 2021 [31]. All these taxa are readily distinguished from each other by unique combinations of dental characters. The high and rather wide, labiolingually compressed tooth crown morphology displayed by the above-described teeth from Czarnogłowy and the presence of a flattened labial crown face, combined with the oval cross-section of the principal cusp, plus the presence of well-developed cutting edges and simple, non-bifurcating folds covering the lower parts of the crown, are dental features that are consistent with those found in teeth attributed to Planohybodus. This hybodontiform has a fossil record ranging from the Middle Jurassic to the Early Cretaceous [29,59,69-71], with the potentially youngest fossil records of Planohybodus being represented by a few fragmentary teeth from the Santonian of the USA [72], but more complete material is needed to unambiguously confirm the presence of Planohybodus in the Late Cretaceous.

Planohybodus falls into three currently accepted species, comprising P. peterboroughensis [59] from the Callovian-Oxfordian of England, P. grossiconus (Agassiz, 1843) [67] 
from the Bathonian of England, Scotland and France [18,59,69] and P. ensis (Woodward, 1916) [73] from the Berriasian-Barremian of England and Spain [59,70,73-76]. While the type species of Planohybodus, P. peterboroughensis, is known from both dental and skeletal material, the remaining two species are known from isolated teeth only. The species P. marki Pinheiro et al., 2013 [77], which has been proposed based on a few fragmentary tooth crowns recovered from the pre-Aptian Early Cretaceous of Brazil, is here regarded as nomen dubium due to the incomplete nature and the absence of any dental features unambiguously supporting its inclusion in the genus Planohybodus. In addition, rare fragmentary teeth from the Berriasian of Bornholm, Denmark, may constitute a yet undescribed species of Planohybodus [59,78], but more complete material is needed to verify this.

Planohybodus apparently was a common and widely distributed constituent of Late Jurassic marine ecosystems, as inferred from abundant fossil occurrences reported from Europe $[26,29,31,79,80]$. In addition, Alvarado-Ortega et al. [40] described a partially preserved tooth attributed to Planohybodus sp. from Kimmeridgian-Tithonian deposits in Mexico, whose generic affinities are here considered dubious due to its incomplete and fragmentary condition. The teeth from Czarnogłowy cannot be assigned to any currently accepted species of Planohybodus, particularly because dental features for use in distinction between $P$. peterboroughensis, $P$. grossiconus and P. ensis mainly relate to differences in main cusp proportions and the number of lateral cusplets, which makes species identification of incomplete tooth crowns difficult. Therefore, the Czarnogłowy teeth are here simply left in open nomenclature as Planohybodus sp.

cf. Meristodonoides sp.

Figure $2 \mathrm{~m}-\mathrm{r}$.

\subsubsection{Material}

Two partially preserved teeth (GG303/17,18).

\subsubsection{Description}

The teeth are represented by two incomplete, labio-lingually compressed crowns displaying a slender, slightly distally inclined main cusp with a round cross-section (Figure 2n, $\mathrm{q}$ ) and moderately well-developed cutting edges. The main cusp displays a mesial and a distal heel at its base. Lateral cusplets are not preserved. The ornamentation is restricted to the lower parts of the labial and lingual crown faces and consists of moderately simple, non-bifurcating vertical folds (Figure $2 \mathrm{~m}, \mathrm{o}, \mathrm{p}, \mathrm{r}$ ).

\subsubsection{Remarks}

Although poorly preserved, the overall morphology displayed by the above-described teeth indicates close morphological resemblance to Meristodonoides, which was originally recognised in the Cretaceous of the USA [68] to include M. rajkovichi (Case, 2001) [81] from the Cenomanian of Minnesota, M. butleri (Thurmond, 1971) [82] from the Aptian or Albian of Texas, M. montanensis (Case, 1978) [83] from the Campanian of Montana and Wyoming and M. novojerseyensis (Case and Cappetta, 2004) [84] from the Maastrichtian of New Jersey, as well as M. multiplicatus Cicimurri et al., 2014 [85] from the SantonianCampanian of Mississippi. The oldest fossil record that can be assigned to Meristodonoides dates back to the Late Jurassic and is represented by a yet undescribed species known from a single partial skeleton from the lower Tithonian of England [26]. In addition, incomplete teeth reminiscent of Meristodonoides were reported from the Kimmeridgian of England [25] and Switzerland [29]. However, the Polish material presented here cannot unambiguously be assigned to Meristondonoides due to its incomplete and fragmentary nature, which consequently led us to assign the above-described teeth from Czarnogłowy to cf. Meristodonoides sp.

Asteracanthus Agassiz, 1837 [67]

Type species: Asteracanthus ornatissimus Agassiz, 1837 [67] 
Asteracanthus ornatissimus Agassiz, 1837 [67]

Figure 3.
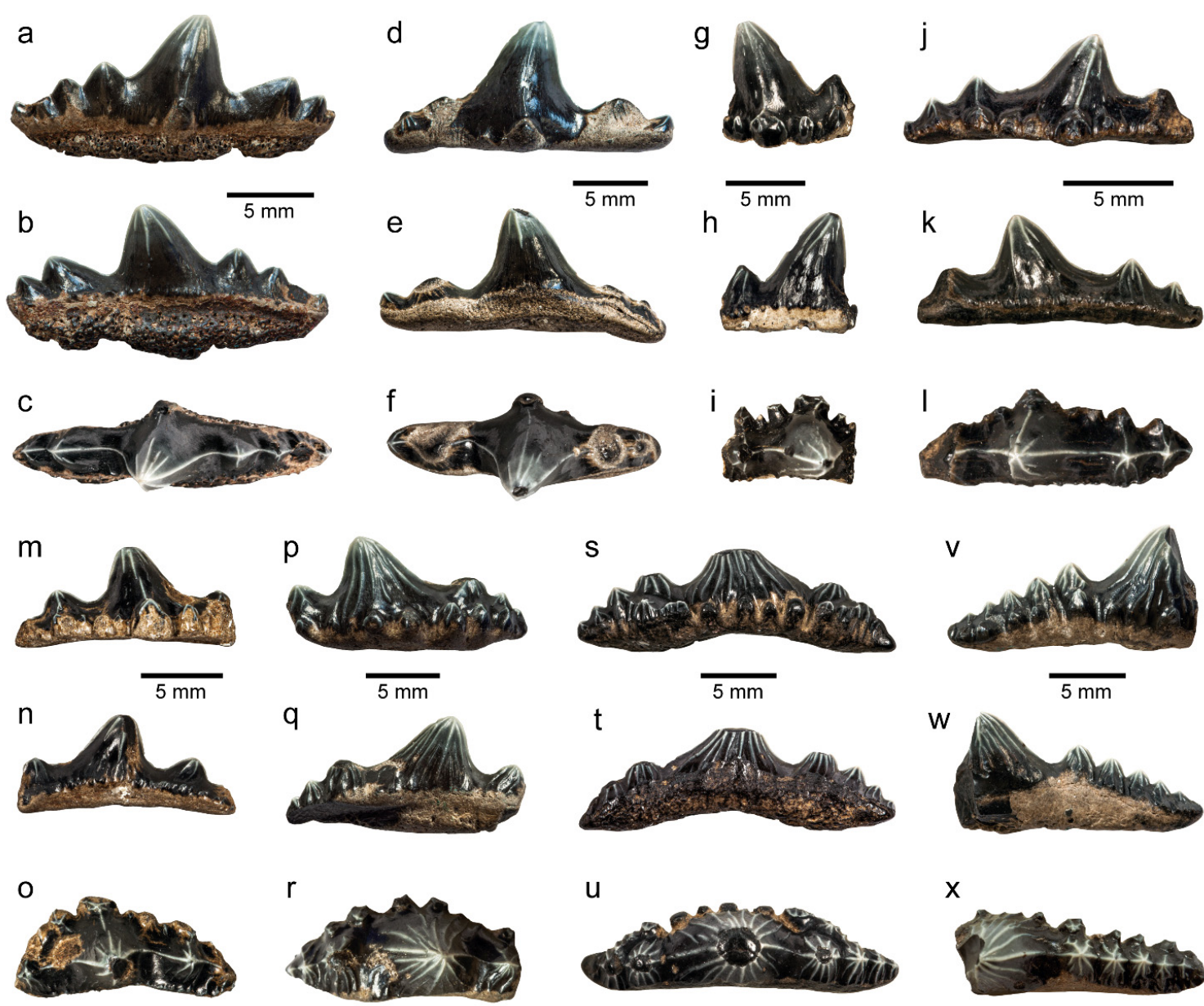

Figure 3. Historically collected hybodontiform teeth from the lower Kimmeridgian of Czarnogłowy, Poland. Asteracanthus ornatissimus Agassiz, 1837. GG 303/19 in (a) labial, (b) lingual and (c) apical view; GG 303/20 in (d) labial, (e) lingual and (f) apical view; GG 303/21 in (g) labial, (h) lingual and (i) apical aspect; GG 303/22 in (j) labial, (k) lingual and (l) apical view; GG 303/23 in (m) labial, (n) lingual and (o) apical view; GG 303/29 in (p) labial, (q) lingual and (r) apical view; GG 303/30 in (s) labial, (t) lingual and (u) apical aspect; GG 303/31 in (v) labial, (w) lingual and (x) apical view.

\subsubsection{Material}

Fifteen incomplete teeth (GG303/19-33).

\subsubsection{Description}

The teeth are characterized by fairly robust multicuspid crowns with a moderately high and robust, conical to somewhat pyramidal main cusp that is slightly distally inclined and flanked by three to five pairs of well-developed lateral cusplets, which diminish in size away from the main cusp. The cutting edges are moderately well-developed and continuous across the cusp and cusplets. The crowns are ornamented with moderate to strongly developed folds that descend from the main cusp and the lateral cusplets labially and lingually, with short, isolated folds occasionally occurring intercalated between them.

All teeth display a series of well-defined bulbous nodes aligned along the labial base of the crown, each one of them being ornamented with short, apically merging folds (Figure $3 a, d, g, j, m, p, s, v)$. In addition, there is a series of very short vertical folds aligned along the lingual base of the crown (Figure $3 b, h, k, n, q)$. The tooth root is present in a 
single tooth only (Figure 3a-c). It is incomplete and has suffered from erosion, displaying numerous very small and irregularly arranged foramina.

The teeth can be further separated into two morphotypes. The first morphotype includes teeth that are relatively narrow labio-lingually with a more slender main cusp and reduced tooth crown ornamentation consisting of a few folds that cover the upper parts of the labial and lingual crown faces (Figure 3a-o). There may be a vertical fold on the labial crown face connecting the apex of the main cusp with the labial node at its base (Figure 3j), which is generally larger than the neighbouring ones (Figure $3 a, d, g, j, m$ ).

The second morphotype encompasses teeth that are more robust, with a stout, somewhat pyramidal main cusp and a more pronounced ornamentation comprising well-defined folds that descend from the main cusp and lateral cusplets down to the base of the tooth crown (Figure $3 \mathrm{p}-\mathrm{x}$ ). The folds covering the teeth of this morphotype may bifurcate basally (Figure $3 \mathrm{r}, \mathrm{u}, \mathrm{x}$ ).

\subsubsection{Remarks}

The above-described teeth from Czarnogłowy were assigned by Hoffmann [49] to Polyacrodus sp. and Hybodus obtusus, respectively. While the genus Polyacrodus Jaekel, 1889 [86] is now considered a nomen dubium [59,87], the species Hybodus obtusus Agassiz, 1843 [67] was recently identified to represent a junior synonym of Asteracanthus ornatissimus [30].

The genus Asteracanthus was originally described by Agassiz [67] from the Late Jurassic of Europe on the basis of isolated dorsal fin spines ornamented with stellate tubercles to include the species A. ornatissimus, A. acutus, A. minor and A. semisulcatus. Since that time, additional species have been attributed to Asteracanthus based on isolated tuberculate dorsal fin spines (e.g., $[17,21,88-90])$. Later, following the discovery of associated dental and skeletal material from the Callovian of England, the genus Strophodus Agassiz, 1838 [67] became a junior synonym of Asteracanthus [18,91]. This taxonomic scheme has generally been accepted until very recently, when the first articulated skeleton with tuberculate fin spines was described from the lower Tithonian of southern Germany by Stumpf et al. [30]. This unique, exceptionally well-preserved female specimen, which was referred to the type species of Asteracanthus, A. ornatissimus, possesses multicuspid grasping teeth consistent with referral to those traditionally assigned to Hybodus obtusus and thus provided strong evidence that Asteracanthus and Strophodus may in fact represent two distinct, valid genera that are readily distinguished from each other by very different dental morphologies [30]. Strophodus is characterized by prominent, uniquely shaped crushing teeth [92], whereas the teeth of Asteracanthus [30] are rather more similar to those of Hybodus [64,93] and Egertonodus Maisey, $1987[64,94]$ than to those of other hybodontiforms, suggesting closer phylogenetic relationships. Nevertheless, the systematic position of both Asteracanthus and Strophodus within Hybodontiformes still remains dubious and unresolved due to the lack of any reliable phylogenetic framework $[30,31]$. Likewise, much uncertainty still surrounds the taxonomic content of Asteracanthus, particularly given the absence of any fossil material suitable for inferring possible morphological characters for use in species differentiation. This led Stumpf et al. [30] to tentatively re-define the genus Asteracanthus as monotypic to include the type species, A. ornatissimus, whose stratigraphic range, as now understood, is Bathonian to Valanginian.

Late Jurassic fossil remains of $A$. ornatissimus are known from several European localities, in particular from those that were formed under fully marine conditions (e.g., [17-20,25,26,95-98]), suggesting that this species might have predominantly been bound to open marine environments. The dentition of the recently described skeleton from the lower Tithonian of southern Germany indicates that the general dental morphology displayed by female individuals of $A$. ornatissimus does not vary between the upper and lower jaw [30]. This suggests that the herein reported teeth from Czarnogłowy, which can actually be separated into two morphotypes, may pertain to different species of Asteracanthus. On the other hand, the presence of two very similar tooth morphotypes co-occurring in the same strata could possibly also be related to intra- rather than interspecific variation, such 
as gynandric and/or ontogenetic heterodonty, which cannot be determined more closely based on the current data available. However, the lower Kimmeridge Clay Formation of England yielded a yet undescribed specimen of Asteracanthus, which is represented by an articulated skull including teeth, cephalic spines and a partial dorsal fin spine [26], whose detailed description may aid a better understanding of the taxonomic content of this enigmatic Mesozoic hybodontiform shark-like chondrichthyan. In consequence, we recommend assigning the above-described teeth from Czarnogłowy to A. ornatissimus until their specific identity can unambiguously be determined.

Acrodontinae Casier, 1959 [99] sensu Maisey, 1989 [58]

Genus Strophodus Agassiz, 1838 [67]

Type species: Strophodus longidens Agassiz, 1838 [67]

Strophodus udulfensis (Leuzinger et al., 2017) [29]

Figures 4 and 5.

a

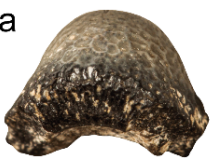

b

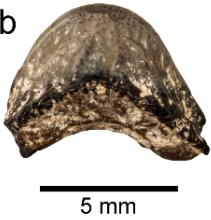

C

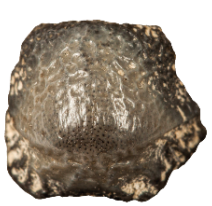

d

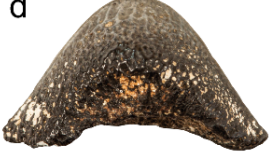

e

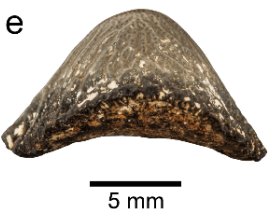

f

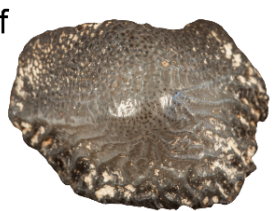

g

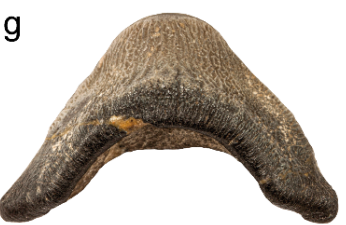

$\mathrm{h}$
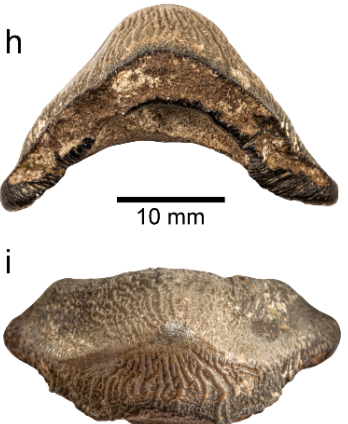
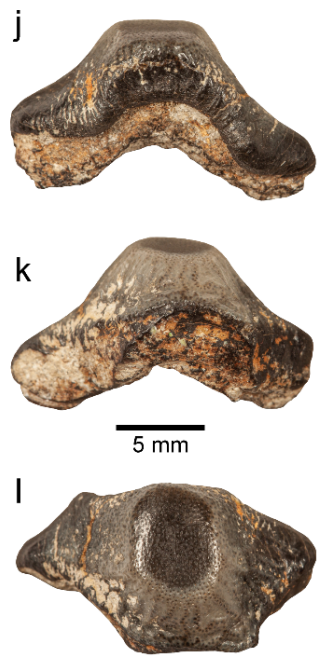

$\mathrm{m}$

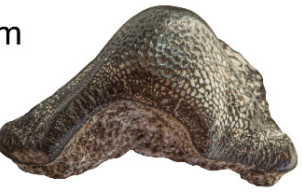

$\mathrm{n}$

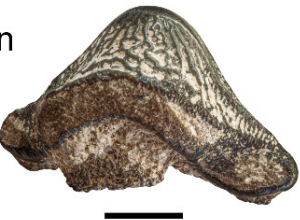

0

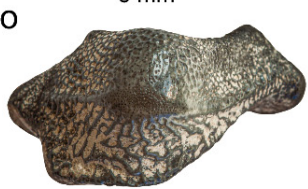

$p$

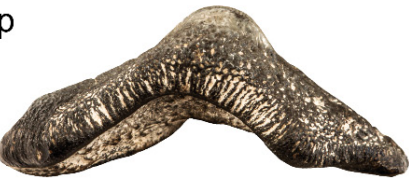

$q$
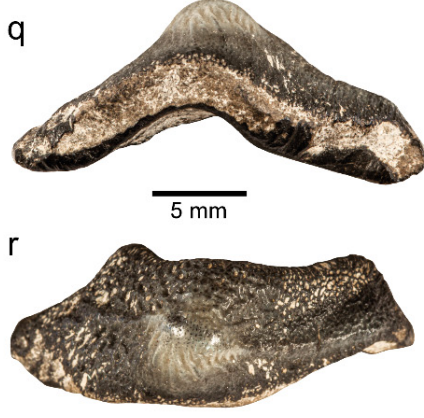

$\mathrm{S}$

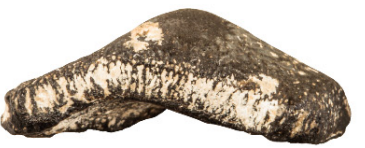

$t$

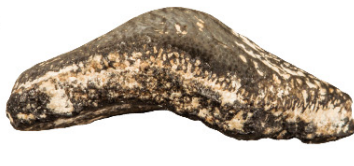

$5 \mathrm{~mm}$

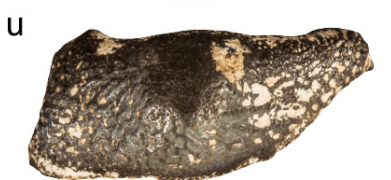

Figure 4. Historically collected hybodontiform teeth from the lower Kimmeridgian of Czarnogłowy, Poland. Strophodus udulfensis (Leuzinger et al., 2017). (a-f) Symphyseal teeth; GG 303/34 in (a) labial, (b) lingual and (c) apical view; GG 303/35 in (d) labial, (e) lingual and (f) apical view. (g-i) First anterior tooth; GG 303/36 in (g) labial, (h) lingual and (i) apical aspect. (j-u) Second anterior teeth; GG 303/37 in (j) labial, (k) lingual and (1) apical view; GG 303/38 in (m) labial, (n) lingual and (o) apical view; (p-u) second lateral teeth; GG 303/39 in (p) labial, (q) lingual and (r) apical view; GG 303/40 in (s) labial, (t) lingual and (u) apical aspect. 
a
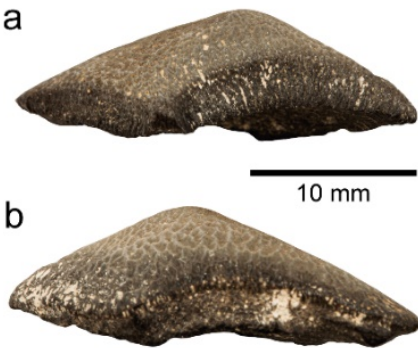

C

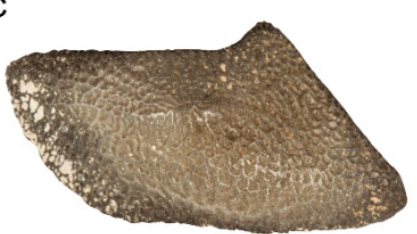

j

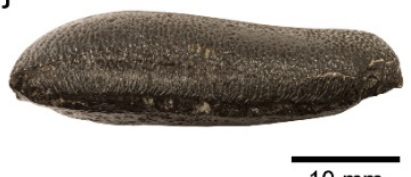

k

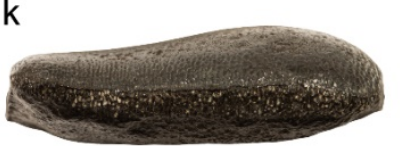

I

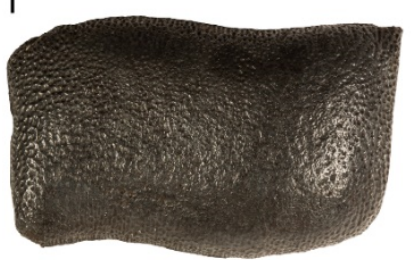

d

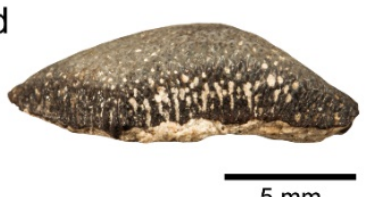

e

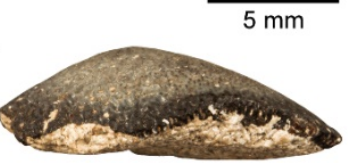

f

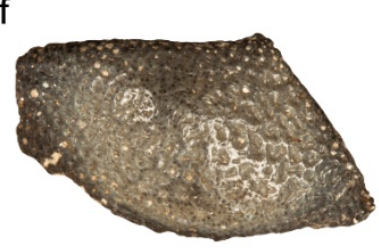

$\mathrm{m}$

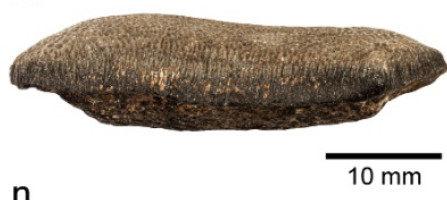

$\mathrm{n}$

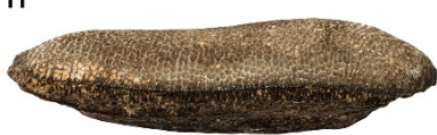

O

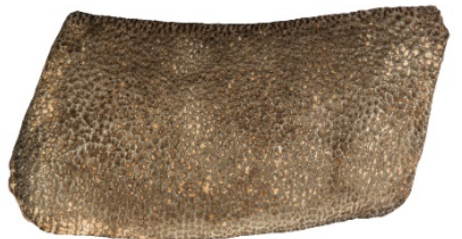

g
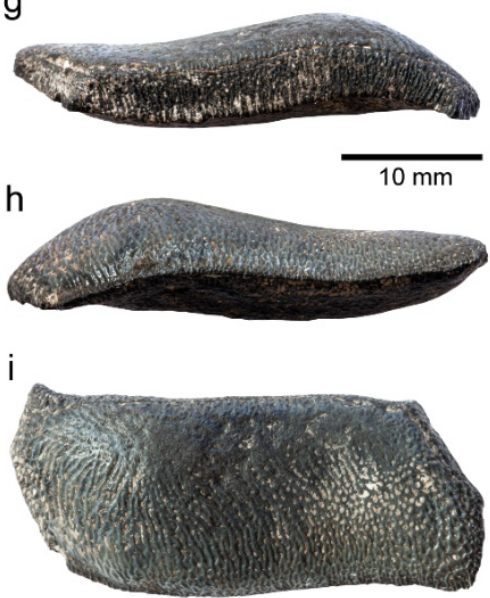

$p$

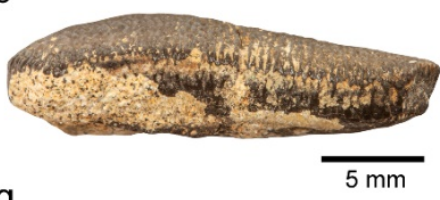

q

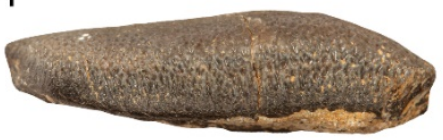

r

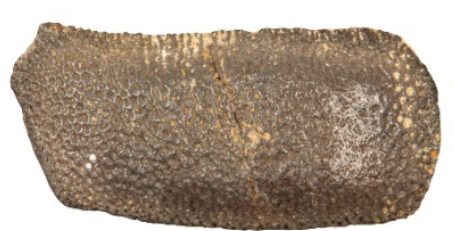

Figure 5. Historically collected hybodontiform teeth from the lower Kimmeridgian of Czarnogłowy, Poland. Strophodus udulfensis (Leuzinger et al., 2017). (a-i) First lateral teeth; GG 303/41 in (a) labial, (b) lingual and (c) apical view; GG 303/42 in (d) labial, (e) lingual and (f) apical view; GG 303/43 in (g) labial, (h) lingual and (i) apical aspect. (j-r) Second lateral teeth; GG 303/44 in (j) labial, (k) lingual and (1) apical view; GG 303/45 in (m) labial, (n) lingual and (o) apical view; GG 303/46 in (p) labial, (q) lingual and (r) apical view.

\subsubsection{Material}

A total of 61 incomplete teeth (GG303/34-94).

\subsubsection{Description}

The teeth are massive and display a relatively high degree of heterodonty. Morphologically, the teeth can be roughly separated into those coming from tooth files of symphyseal (Figure 4a-f), anterior (Figure $4 \mathrm{~g}-\mathrm{u}$ ) and lateral positions (Figure 5). Posterior teeth are absent in the fossil assemblage from Czarnogłowy. The root is missing in most teeth or is just partially preserved. In addition, the occlusal crown face may be somewhat damaged due to wear.

Symphyseal teeth are short mesio-distally and strongly domed, displaying a subrectangular outline in occlusal view (Figure 4c,f). There is a weak transverse crest extending across the occlusal face of the crown. The crown exhibits a complex ornamentation pattern consisting of frequently branching folds on the lingual half of the crown (Figure $4 \mathrm{~b}, \mathrm{e})$ and reticulate folds on the labial half, which gives it a rough, more or less regularly pitted surface texture (Figure $4 a, d$ ). 
The teeth of the first anterior file (Figure $4 \mathrm{~g}-\mathrm{i}$ ) are relatively wide mesio-distally, symmetrical and strongly arched. The domed area is wide mesio-distally and smoothly rounded in labio-lingual aspect (Figure $4 \mathrm{~g}, \mathrm{~h}$ ). There is a moderately well-developed transverse crest that runs across the crown (Figure 4i). The ornamentation covering the occlusal surface of the crown comprises anastomosing folds on the lingual half (Figure $4 \mathrm{~h}$ ) and reticulate folds on the labial half (Figure $4 \mathrm{~g}$ ).

The anterior teeth of the second file (Figure $4 \mathrm{j}-\mathrm{u}$ ) are expanded mesio-distally and moderately arched and asymmetrical, the mesial extremity being slightly more elongated and tapered in occlusal view than the distal one (Figure $41,0, r, u)$. The crown exhibits a weak transverse crest, which may be absent in smaller teeth (Figure $4 \mathrm{u}$ ). Similar to symphyseal and first anterior teeth, the crown is ornamented by branching folds covering the lingual half (Figure $4 k, n, q, t)$ and is reticulated on the labial half (Figure $4 \mathrm{j}, \mathrm{m}, \mathrm{p}, \mathrm{s}$ ).

The lateral teeth of the first file (Figure 5a-i) are wide mesio-distally and only slightly domed. They possess either a somewhat lenticular (Figure 5c,f) or parallelogram-shaped (Figure 5i) outline in occlusal view and lack a transverse crest. While in those teeth with a lenticular outline the domed area is positioned at about the centre of the crown, the parallelogram-shaped teeth are gently domed mesially. The tooth crown ornamentation displays a reticulate pattern (Figure 5c,f), which may turn into fine branching folds (Figure 5i).

The lateral teeth of the second file (Figure 5j-r) are larger and broader labio-lingually, exhibiting a subrectangular outline in occlusal aspect (Figure 51,o,r). They are slightly domed mesially and lack a transverse crest. The tooth crown is entirely reticulated.

\subsubsection{Remarks}

The prominent crushing type teeth from Czarnogłowy were initially assigned to Asteracanthus ornatissimus by Hoffmann [49] following the long accepted taxonomic scheme of Woodward [18,89]. However, since this taxonomic concept has been challenged [30], these teeth are here assigned to Strophodus, which was apparently one of the most common and widely distributed Mesozoic hybodontiforms, given that fossil occurrences attributable to Strophodus have so far been reported almost worldwide from Middle Triassic to Early Cretaceous strata (e.g., [30,71,92,100-105]). Strophodus, as currently understood, encompasses at least 13 species, 11 of which have been named to date. These comprise (in stratigraphic order):

1. S. cf. reticulatus Agassiz, 1838 [67] from the Middle Triassic of Switzerland [100].

2. S. smithwoodwardi (Peyer, 1946) [106] from the Toarcian of Switzerland.

3. S. dunaii (Szabó and Főzy, 2020) [92] from the Aalenian of Hungary.

4. S. tenuis Agassiz, 1838 [67] from Aalenian-Bathonian strata of Germany and England [59].

5. S. longidens Agassiz, 1838 [67], which represents the type species originating from the Bathonian of France.

6. S. magnus Agassiz, 1838 [67] from the Bathonian of England, France and India [59,71,107].

7. S. indicus Sharma and Singh, 2021 [71] from the Bathonian of India.

8. S. jaisalmerensis Kumar et al., 2021 [108] from the Bathonian of India.

9. S. medius Owen, 1869 [109] from the Bathonian-Callovian of France, England and India $[59,71]$.

10. S. reticulatus Agassiz, 1838 [67], which is probably the temporally and spatially most widespread species being reported from the Bathonian-Tithonian of England, France, Switzerland, Germany and Hungary [26,30,59,92,106,110].

11. S. subreticulatus Agassiz, 1838 [67] from the Kimmeridgian of Switzerland.

12. S. udulfensis (Leuzinger et al., 2017) [29] from the Kimmeridgian of Switzerland and possibly England.

13. Strophodus sp. from the Tithonian of Germany [111].

Morphological characters for use in species identification mainly focus on dental traits due to the lack of suitable skeletal material. There are just a few species that are known by articulated or at least partially articulated dentitions, such as Strophodus medius, S. reticulatus 
and S. magnus $[59,92,107]$. These species share very similar dentition patterns consisting of up to six tooth files on each side of the jaws, which can be further separated into two files of relatively high, strongly arched anterior teeth, two files of enlarged lateral teeth and one or two files of small posterior teeth. In addition, a single file of symphyseal teeth occurs, restricted to the lower jaw [111], a condition shared with other hybodontiforms such as Egertonodus and Asteracanthus [30,75,94].

The overall morphology displayed by the teeth from Czarnogłowy is closest to that of Strophodus udulfensis from the Kimmeridgian of Switzerland [29]. In addition, teeth of this species may also occur in the Kimmeridgian of England [26,29]. Differences between the above-described teeth from Czarnogłowy and those of $S$. udulfensis include slightly divergent ornamentation patterns in the teeth of the first lateral file, in particular in those exhibiting a lenticular outline, which are entirely reticulated in the Czarnogłowy teeth, unlike in S. udulfensis, in which these teeth show a more complex ornamentation pattern mainly consisting of frequently branching folds. However, since such minor differences in tooth crown ornamentation do not necessarily mirror heterospecificity, mainly because it could also possibly be explained by gynandric heterodonty, the above-described teeth are here assigned to $S$. udulfensis, thus extending the geographical range of this species to the marginal marine ecosystems south of Fennoscandia.

The teeth from Czarnogłowy vary in size (see, e.g., Figure 5a-f), which is indicative of different ontogenetic stages, suggesting that they originally derived from both subadult and adult individuals.

\section{Discussion}

\subsection{Palaeoecology}

The hybodontiform faunal assemblage from the lower Kimmeridgian of Czarnogłowy comprises at least four large-toothed taxa characterized by different dental features that hint at a wide variety of possible feeding ecologies. While the tooth morphologies displayed by Planohybodus sp. and cf. Meristodonoides sp. suggest an adaptation towards tearing prey [59], the more robust teeth of Asteracanthus ornatissimus form an effective grasping dentition suitable for processing a wide dietary spectrum [30]. This contrasts with Strophodus udulfensis, whose teeth form a prominent, well-developed durophagous crushing dentition [29,92].

Chondrichthyans recovered from the late Oxfordian to early Tithonian succession of Czarnogłowy, aside from the historically collected hybodontiform assemblage presented in this contribution, are known from very rare crown elasmobranch teeth of uncertain stratigraphic origin described by Hoffmann [49], comprising a total number of eight fragmentary teeth, four of which can be identified below the order level to include the squatiniform Pseudorhina alifera (Münster, 1842) [112], the heterodontiform Paracestracion falcifer Wagner, 1857 [113] and the carcharhiniform Palaeoscyllium formosum Wagner, 1857 [113]. All these taxa are typical components of European Late Jurassic chondrichthyan associations, indicating high dispersal abilities [114]. However, whether the apparent dominance of hybodontiforms reflects an ecological signal, or simply a collection bias focused on macroscopic rather than microscopic chondrichthyan remains, is unclear. Evidently, the hybodontiform Strophodus udulfensis is represented by dental material that refers to different ontogenetic stages, suggesting that the marginal marine environments south of Fennoscandia might have provided shelter that maximized growth rates and at the same time minimized the risk of predation. This is in good accordance with other reported occurrences of S. udulfensis [29], which together with stable isotope data [115] suggest that this species was a shallow-water-preferring taxon, which may have moved to low-salinity environments for reproduction.

\subsection{Late Jurassic Hybodontiform Diversity and Distribution Patterns}

The diversity dynamics of Mesozoic hybodontiforms are still poorly understood and have yet to be statistically established. This is mainly because most species are known from 
isolated teeth and/or fin spines only, which commonly display morphological traits that are either ambiguous or broadly distributed among representatives of this enigmatic group of extinct shark-like chondrichthyans. Conversely, articulated or disarticulated skeletons, which provide important taxonomic but also ecomorphological information, remain rather scarce in the hybodontiform fossil record (e.g., [30,31,64,94,116-118]), particularly due to specific taphonomic constraints that hinder the preservation of their poorly mineralized cartilaginous endoskeletons. This discrepancy has led to different taxonomic and systematic schemes [16,58,87], pending further research effort. Nevertheless, it is evident that hybodontiforms constituted a major component of Mesozoic marine ecosystems, especially during the Jurassic, the time when they flourished and expanded into various ecological niches, occurring in fully to marginal marine and even continental depositional environments (e.g., [24-26,29,35,59,93,118,119]). The vast majority of reported Late Jurassic hybodontiform occurrences come from Europe, which have received considerable research attention since the 19th century (e.g., [18,20-31,91,97]). Conversely, records of non-European Late Jurassic hybodontiforms are rather rare, patchy and strongly biased towards continental environments [32-40]. Nevertheless, despite the heterogenous availability of productive localities, some interesting points, at least on a more local scale, can be deduced from the here reported hybodontiform assemblage from the lower Kimmeridgian of Czarnogłowy.

During the Late Jurassic, wide areas of Europe were covered by a shallow epicontinental shelf sea that formed the southern part of a trans-Pangaean seaway linking the low-palaeolatitudinal Tethys Ocean to the high-palaeolatitudinal Boreal Sea [120,121]. This allowed the migration of marine vertebrates, such as marine reptiles [46], which according to Tyborowski and Błażejowski [48] display a faunal provincialism that falls into a transitional palaeobiogeographic belt connecting the Tethyan and Boreal faunal provinces (in contrast, see [122]). Conversely, distribution patterns of European Late Jurassic crown elasmobranchs display fairly homogenous faunal compositions, reflecting minor provincialism without boreal influences [114]. Similarly, quite homogeneous distribution patterns are indicated for large-bodied hybodontiforms such as Planohybodus, Asteracanthus, Strophodus and possibly Meristodonoides, as inferred from the herein reported fossil chondrichthyan assemblage from Czarnogłowy, which shows close affinities with other European Late Jurassic hybodontiform-bearing localities, in particular to those from England [25,26,30,31], France $[20,79,80,98]$ and Switzerland [29] (Figure 6; note that there is also a historically described tooth that is consistent with Asteracanthus from the Oxfordian-Kimmeridgian of Inowrocław in central Poland [19]). On the other hand, small-bodied hybodontiforms such as the lonchidiid Parvodus Rees and Underwood, 2008 [123] appear to have been rare and predominantly bound to marginal marine environments with reduced or fluctuating salinities (e.g., $[23,24,80])$. This suggests that their apparently restricted facies distribution might have been due to biotic and/or abiotic constraints, although it might also reflect a collection bias since their small teeth are likely to have been overlooked in the past.

As common predators occupying higher trophic levels in a wide range of marine Late Jurassic ecosystems, large-bodied hybodontiforms such as Planohybodus, Asteracanthus and Strophodus might have had an impact on crown group elasmobranchs, which experienced a diversity stasis during the Late Jurassic before attaining a subsequent diversity increase during the Early Cretaceous $[5,124,125]$. Therefore, differences in habitat and/or prey preferences might have served as controlling factors reducing the apparent competition potential between Late Jurassic hybodontiforms and their more advanced chondrichthyan counterparts $[29,115]$. 


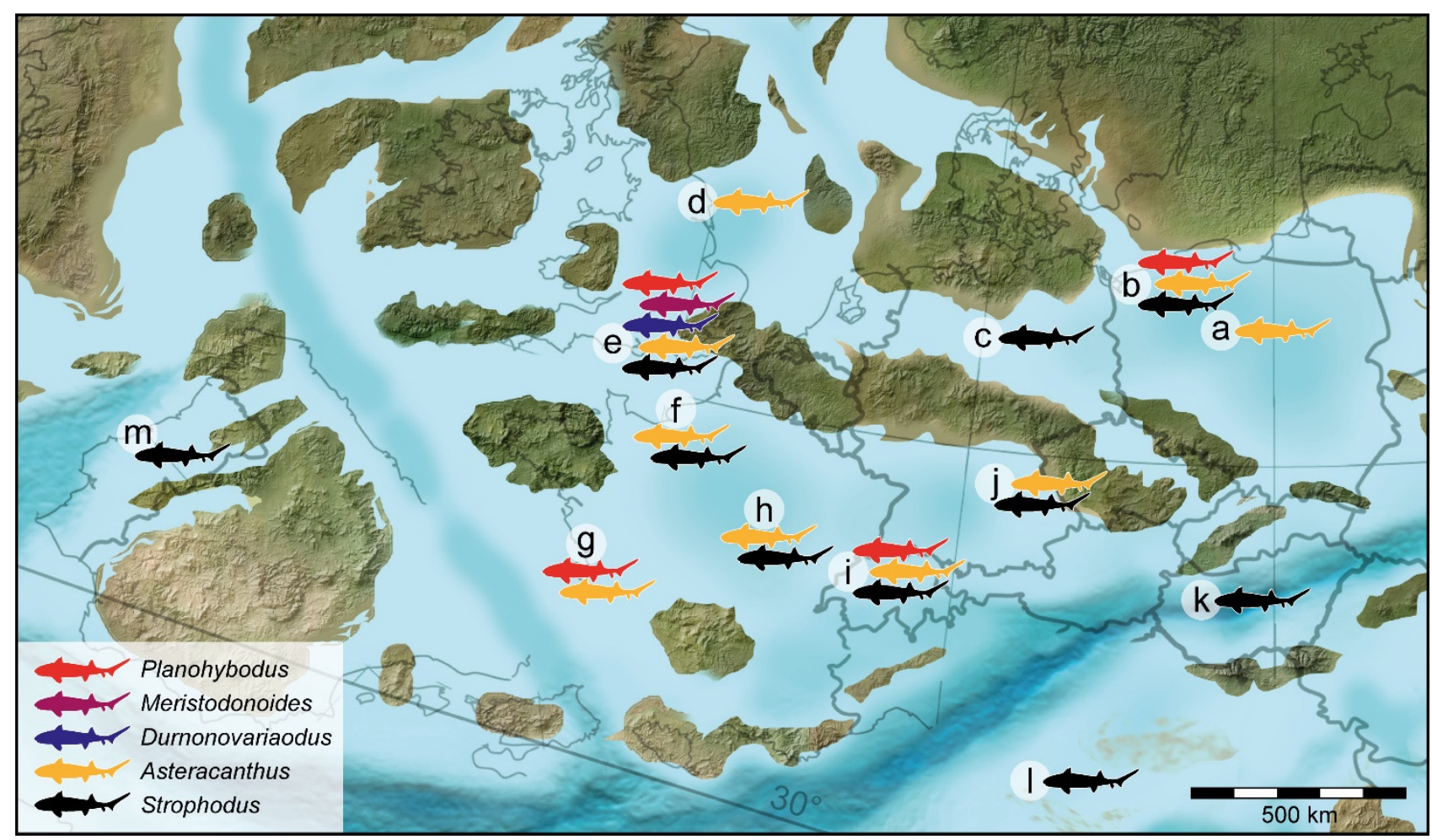

Figure 6. Rough reconstruction of Europe during the Late Jurassic depicting reported occurrences of large-toothed hybodontiform genera (taxa that cannot confidently be identified at genus level are excluded). (a) Oxfordian-Kimmeridgian of central Poland [19]; (b) Kimmeridgian of northwestern Poland (this study); (c) Kimmeridgian of northern Germany [17]; (d) Oxfordian of northern England [97]; (e) Oxfordian-Tithonian of southern England [25,26,30,31]; (f) Kimmeridgian of north-western France [20]; (g) Tithonian of western France [20,79,80]; (h) Oxfordian of central France [98]; (i) Kimmeridgian of Switzerland [29]; (j) Kimmeridgian of southern Germany [28,30,111]; (k) Tithonian of Hungary [92]; (1) Kimmeridgian-Tithonian of Italy [105]; (m) Kimmeridgian of Portugal [21,22]. Palaeogeographic map (c) 2011 Colorado Plateau Geosystems Inc., Scottsdale, AZ, USA.

The genera Planohybodus, Asteracanthus and Strophodus were common and widespread during the Jurassic, especially during the Middle and Late Jurassic, the time when they reached their highest species diversity [30,59,92]. By the Early Cretaceous, their species diversity dropped significantly, resulting in a fossil record dominated by small-toothed forms, which predominantly occur in marginal marine depositional environments with reduced or fluctuating salinities (e.g., [70,74-76,126]). Potential causes driving the postJurassic diversity decline in fully marine hybodontiforms may include biotic constraints such as increasing risk of niche overlap with rapidly diversifying crown group elasmobranchs $[5,118]$, probably accompanied by disruptions in the availability of preferred food resources (see [79,127]) caused by the environmental perturbations at the J/K boundary [1]

\section{Conclusions}

The present study, in which we reassessed a historically collected hybodontiform dental assemblage from the lower Kimmeridgian of Czarnogłowy initially described by Hoffmann [49], contributes to our knowledge of Mesozoic marine vertebrate life, providing promising clues for better understanding Late Jurassic chondrichthyan diversity and distribution patterns.

The taxonomic composition consisting of Asteracanthus ornatissimus, Strophodus udulfensis and Planohybodus sp., as well as cf. Meristodonoides sp., which is remarkable in that there are only a very few Mesozoic hybodontiform assemblages with more large-toothed genera or even species $[31,59,118]$, demonstrates close faunal affinities to other European Late 
Jurassic hybodontiform-bearing localities, indicating biogeographically homogenous distribution patterns characterized by large-bodied epipelagic forms of intermediate trophic position that were able to cross larger marine areas. This parallels patterns of biogeographic homogeneity displayed by crown elasmobranchs, which rapidly diversified from the Early Cretaceous onwards to become the most dominant chondrichthyan group. By contrast, post-Jurassic hybodontiform communities are dominated by small-bodied taxa that are largely confined to marginal marine environments with reduced salinities, indicating a major reorganization of chondrichthyan communities during the Early Cretaceous. This suggests that the dispersal abilities of post-Jurassic hybodontiforms were probably limited by both abiotic stress and biotic constraints, such as an increasing risk of competition from rapidly radiating crown elasmobranchs.

Author Contributions: Conceptualization, S.S., S.M. and J.K.; methodology, S.S.; validation, S.S.; formal analysis, S.S.; investigation, S.S.; data curation, S.S.; visualization, S.S.; writing—original draft preparation, S.S., S.M. and J.K.; writing-review and editing, S.S., S.M. and J.K. All authors have read and agreed to the published version of the manuscript.

Funding: Open Access Funding by the University of Vienna.

Institutional Review Board Statement: Not applicable.

Data Availability Statement: All specimens in this study are housed at the Institute of Geography and Geology, University of Greifswald, Germany.

Acknowledgments: We thank Charlie Underwood (Birkbeck, University of London) and Gilles Cuny (Université Claude Bernard Lyon 1) for valuable discussions and support. Ron Blakey (Colorado Plateau Geosystems Inc.) is thanked for permission to use his palaeogeographic map. The authors are grateful to four anonymous reviewers, whose comments improved the quality of the manuscript.

Conflicts of Interest: The authors declare no conflict of interest.

\section{References}

1. Tennant, J.P.; Mannion, P.D.; Upchurch, P.; Sutton, M.D.; Price, G.D. Biotic and environmental dynamics through the Late Jurassic-Early Cretaceous transition: Evidence for protracted faunal and ecological turnover. Biol. Rev. 2017, 92, 776-814. [CrossRef] [PubMed]

2. Upchurch, P.; Mannion, P.D.; Benson, R.B.J.; Butler, R.J.; Carrano, M.T. Geological and anthropogenic controls on the sampling of the terrestrial fossils record: A case study from the Dinosauria. In Comparing the Geological and Fossil Records: Implications for Biodiversity Studies; McGowan, A.J., Smith, A.B., Eds.; Special Publications 358; The Geological Society: London, UK, 2011; pp. 209-240. [CrossRef]

3. Friedman, M.; Sallan, L.C. Five hundred million years of extinction and recovery: A phanerozoic survey of large-scale diversity patterns in fishes. Palaeontology 2012, 55, 707-742. [CrossRef]

4. Benson, R.B.J.; Druckenmiller, P.S. Faunal turnover of marine tetrapods during the Jurassic-Cretaceous transition. Biol. Rev. 2014, 89, 1-23. [CrossRef] [PubMed]

5. Guinot, G.; Cavin, L. 'Fish' (Actinopterygii and Elasmobranchii) diversification patterns through deep time. Biol. Rev. 2016, 91, 950-981. [CrossRef] [PubMed]

6. Stubbs, T.L.; Benton, M.J. Ecomorphological diversifications of Mesozoic marine reptiles: The roles of ecological opportunity and extinction. Paleobiology 2016, 42, 547-573. [CrossRef]

7. Tennant, J.P.; Mannion, P.D.; Upchurch, P. Sea level regulated tetrapod diversity dynamics through the Jurassic/Cretaceous interval. Nat. Commun. 2016, 7, 12737. [CrossRef]

8. Compagno, L.J.V. Interrelationships of living elasmobranchs. Zool. J. Linn. Soc. 1973, 53, 15-61.

9. Cappetta, H.; Buffetaut, E.; Cuny, G.; Suteethorn, V. A new elasmobranch assemblage from the Lower Cretaceous of Thailand. Palaeontology 2006, 49, 547-555. [CrossRef]

10. Cuny, G.; Ouaja, M.; Srarfi, D.; Schmitz, L.; Buffetaut, E.; Benton, M.J. Fossil sharks from the Early Cretaceous of Tunisia. Rev. Paléobiol. 2004, 9, 127-142.

11. Cuny, G.; Suteethorn, V.; Khamha, S.; Buffetaut, E.; Philippe, M. A new hybodont shark assemblage from the Lower Cretaceous of Thailand. Hist. Biol. 2006, 18, 21-31. [CrossRef]

12. Cuny, G.; Suteethorn, V.; Khamha, S.; Buffetaut, E. Hybodont sharks from the Lower Cretaceous Khok Kruat Formation of Thailand, and hybodont diversity during the Early Cretaceous. In Fishes and the Break-up of Pangaea; Cavin, L., Longbottom, A., Richter, M., Eds.; Special Publications 295; The Geological Society: London, UK, 2008; pp. 93-107. [CrossRef] 
13. Cuny, G.; Cavin, L.; Suteethorn, V. A new hybodont with a cutting dentition from the Lower Cretaceous of Thailand. Cret. Res. 2009, 30, 515-520. [CrossRef]

14. Cuny, G.; Laojumpon, C.; Cheychiw, O.; Lauprasert, K. Fossil vertebrate remains from Kut Island (Gulf of Thai land, Early Cretaceous). Cret. Res. 2010, 31, 415-423. [CrossRef]

15. Cuny, G. Freshwater hybodont sharks in Early Cretaceous ecosystems: A review. In Bernissart Dinosaurs and Early Cretaceous Terrestrial Ecosystems; Godefroit, P., Ed.; Indiana University Press: Bloomington, IN, USA, 2012; pp. 518-529.

16. Cappetta, H. Chondrichthyes: Mesozoic and Cenozoic Elasmobranchii. In Handbook of Paleoichthyology, 3E; Verlag Dr. Friedrich Pfeil: München, Germany, 2012; p. 512.

17. Fricke, K. Die fossilen Fische aus den oberen Juraschichten von Hannover. Palaeontographica 1876, 22, 347-398.

18. Woodward, A.S. Catalogue of the Fossil Fishes in the British Museum (Natural History); Part I; British Museum: London, UK, 1889; p. 474.

19. Gallinek, E. Der obere Jura bei Inowrazlaw in Posen. Verh. Kais. Russ.-Miner. Ges. St. Petersbg. 1895, 33, $353-427$.

20. Candoni, L. Deux faunes inédites de sélaciens dans le Jurassique terminal Français: Premiers résultats stratigraphiques. Bull. Tr. Soc. Géol. Norm. Amis Muséum Havre 1995, 82, $29-49$.

21. Kriwet, J. Beitrag zur Kenntnis der Fisch-Fauna des Ober-Jura (unteres Kimmeridge) der Kohlengrube Guimarota bei Leiria, Mittel-Portugal: 1. Asteracanthus biformatus n. sp. (Chondrichthyes: Hybodontoidea). Berl. Geowiss. Abh. 1995, E16, 683-691.

22. Kriwet, J. Late Jurassic elasmobranch and actinopterygian fishes from Portugal and Spain. Cuad. Geol. Ibér. 1998, 24, 241-260.

23. Kriwet, J. Late Jurassic selachians (Chondrichthyes: Hybodontiformes, Neoselachii) from Central Portugal. N. Jb. Geol. Paläontol. Mh. 2004, 4, 233-256. [CrossRef]

24. Duffin, C.J.; Thies, D. Hybodont shark teeth from the Kimmeridgian (Late Jurassic) of northwest Germany. Geol. Palaeontol. 1997, 31, 235-256.

25. Underwood, C.J. Sharks, rays and a chimaeroid from the Kimmeridgian (Late Jurassic) of Ringstead, southern England. Palaeontology 2002, 45, 297-325. [CrossRef]

26. Underwood, C.J. 2. Sharks and rays. In Fossils of the Kimmeridge Clay Formation. Vol. 2: Vertebrate Palaeontology; Martill, D.M., Etches, S., Eds.; Field Guide to Fossils 16; Palaeontological Association: London, UK, 2020; pp. 14-32.

27. Kriwet, J.; Klug, S. Late Jurassic selachians (Chondrichthyes, Elasmobranchii) from southern Germany: Re-evaluation on taxonomy and diversity. Zitteliana A 2004, 44, 67-95.

28. Kriwet, J.; Klug, S. Knorpelfische (Chondrichthyes). In Solnhofen. Ein Fenster in die Jurazeit; Arratia, G., Schultze, H.-P., Tischlinger, H., Viohl, G., Eds.; Verlag Dr. Friedrich Pfeil: München, Germany, 2015; pp. 334-359.

29. Leuzinger, L.; Cuny, G.; Popov, E.; Billon-Bruyat, J.-P. A new chondrichthyan fauna from the Late Jurassic of the Swiss Jura (Kimmeridgian) dominated by hybodonts, chimaeroids and guitarfishes. Pap. Palaeontol. 2017, 3, 471-511. [CrossRef]

30. Stumpf, S.; López-Romero, F.A.; Kindlimann, R.; Lacombat, F.; Pohl, B.; Kriwet, J. A unique hybodontiform skeleton provides novel insights into Mesozoic chondrichthyan life. Pap. Palaeontol. 2021, 7, 1479-1505. [CrossRef]

31. Stumpf, S.; Etches, S.; Underwood, C.J.; Kriwet, J. Durnonovariaodus maiseyi gen. et sp. nov., a new hybodontiform shark-like chondrichthyan from the Upper Jurassic Kimmeridge Clay Formation of England. PeerJ 2021, 9, e11362. [CrossRef] [PubMed]

32. Cuny, G.; Suteethorn, V.; Khamha, S. A review of the hybodont sharks from the Mesozoic of Thailand. In Proceedings of the International Conference on Geology, Geotechnology and Mineral Resources of Indochina, GEOINDO 2005, Khon Kaen, Thailand, 28-30 November 2005; Wanakao, L., Ed.; Department of Geotechnology: Khon Kaen, Thailand, 2005; pp. 588-593.

33. Cuny, G.; Suteethorn, V.; Khamha, S.; Lauprasert, K.; Srisuk, P.; Buffetaut, E. The Mesozoic fossil record of sharks in Thailand In Proceedings of the International Conference on Geology of Thailand: Towards Sustainable Development and Sufficiency Economy, GEOTHAI'2007, Bangkok, Thailand, 21-22 November 2007; Tantiwanit, W., Ed.; Department of Mineral Resources: Bangkok, Thailand, 2007; pp. 349-354.

34. Cuny, G.; Liard, R.; Deesri, U.; Liard, T.; Khamha, S.; Suteethorn, V. Shark faunas from the Late Jurassic-Early Cretaceous of northeastern Thailand. Paläontol. Z. 2014, 88, 309-328. [CrossRef]

35. Klug, S.; Tütken, T.; Wings, O.; Pfretzschner, H.-U.; Martin, T. A Late Jurassic freshwater shark assemblage (Chondrichthyes, Hybodontiformes) from the southern Junggar Basin, Xinjiang, Northwest China. Palaeobiodivers. Palaeoenviron. 2010, 90, $241-257$. [CrossRef]

36. Goodwin, M.B.; Clemens, W.A.; Hutchison, J.H.; Wood, C.B.; Zavada, M.S.; Kemp, A.; Duffin, C.J.; Schaff, C.R. First Mesozoic terrestrial vertebrates with associated palynostratigraphic dates from the northwestern Ethiopian Plateau. J. Vert. Paleontol. 1999, 19, 728-741. [CrossRef]

37. Arratia, G.; Kriwet, J.; Heinrich, W.-D. Selachians and actinopterygians from the Upper Jurassic of Tendaguru, Tanzania. Mitt. Mus. Für Naturkd. Berl. Geowiss. Reihe 2002, 5, 207-230.

38. Cione, A.L.; Acosta Hospitaleche, C.; Mennucci, J.A.; Cocca, S. The first Triassic-Jurassic shark of South America. N. Jb. Geol. Paläontol. Mh. 2002, 1, 9-18. [CrossRef]

39. Soto, M.; Perea, D.; Toriño, P. New remains of Priohybodus arambourgi (Hybodontiformes: Hybodontidae) from Late Jurassice? Earliest Cretaceous deposits in Uruguay. Cret. Res. 2012, 35, 118-123. [CrossRef]

40. Alvarado-Ortega, J.; Barrientos-Lara, J.I.; Espinosa-Arrubarrena, L.; Melgarejo-Damián, M.D.P. Late Jurassic marine vertebrates from Tlaxiaco, Oaxaca State, southern Mexico. Paleontol. Electron. 2014, 17, 1-25. [CrossRef]

41. Dames, W. Verhandlungen der Gesellschaft. 1. Protokoll der November-Sitzung. Z. Dtsch. Geol. Gesell. 1888, 40, 777-778. 
42. Deecke, W. Geologie von Pommern; Verlag Gebrüder Borntraeger: Berlin, Germany, 1907; p. 302.

43. Kin, A.; Gruszczynński, M.; Martill, D.; Marshall, J.D.; Błażejowski, B. Palaeoenvironment and taphonomy of a Late Jurassic (Late Tithonian) Lagerstätte from central Poland. Lethaia 2013, 46, 71-81. [CrossRef]

44. Young, M.T.; Hua, S.; Steel, L.; Foffa, D.; Brusatte, S.L.; Thüring, S.; Mateus, O.; Ruiz-Omeñaca, J.I.; Havlik, P.; Lepage, Y.; et al. Revision of the Late Jurassic teleosaurid genus Machimosaurus (Crocodylomorpha, Thalattosuchia). R. Soc. Open Sci. 2014, 1, 140222. [CrossRef]

45. Błażejowski, B.; Lambers, P.; Gieszcz, P.; Tyborowski, D.; Binkowski, M. Late Jurassic jaw bones of Halecomorph fish (Actinopterygii: Halecomorphi) studied with X-ray microcomputed tomography. Paleontol. Electron. 2015, 18, 1-10. [CrossRef]

46. Tyborowski, D. A new ophthalmosaurid ichthyosaur from the Late Jurassic of Owadów-Brzezinki Quarry, Poland. Acta Palaeontol. Pol. 2016, 61, 791-803. [CrossRef]

47. Tyborowski, D. Large predatory actinopterygian fishes from the Late Jurassic of Poland studied with X-ray microtomography. N. Jb. Geol. Paläontol. Abh. 2017, 283, 161-172. [CrossRef]

48. Tyborowski, D.; Błażejowski, B. New marine reptile fossils from the Late Jurassic of Poland with implications for vertebrate faunas palaeobiogeography. Proc. Geol. Assoc. 2019, 130, 741-751. [CrossRef]

49. Hoffmann, N. Knorpel- und Knochenfische aus dem Oberjura von Nordwestpolen. Diploma Thesis, University of Greifswald, Greifswald, Germany, 2006; p. 109.

50. Rees, J. Neoselachian sharks from the Callovian-Oxfordian (Jurassic) of Ogrodzieniec, Zawiercie Region, Southern Poland. Palaeontology 2010, 53, 887-902. [CrossRef]

51. Brüggemann, L.W. Ausführliche Beschreibung des Gegenwärtigen Zustandes des Königl. Preußischen Herzogthums Vor- und Hinterpommern-Theil 2, Band 1: Beschreibung der zu dem Gerichtsbezirk der Königl. Landescollegien in Stettin gehörigen Hinterpommerschen; Kreise, H.G., Ed.; Essenbart: Stettin, Poland, 1784; p. 460.

52. Dadlez, R.; Marek, S.; Pokorski, J. Geological Map of Poland without Cainozoic Deposits (1:1.000.000); Polish Geological Institute: Warszawa, Poland, 2010.

53. Dohm, B. Über den oberen Jura von Zarnglaff i. P. und seine Ammonitenfauna. Abh. Geol.-Palaeontol. Inst. Univ. Greifsw. 1925, $4,1-40$

54. Richter, D. Geologischer Führer durch die Zarnglaff-Schwanteshagener Malmbrüche. Mitt. Geol.-Palaeontol. Inst. Univers. Greifsw. 1931, 7, 1-24.

55. Wilczyñski, A. Stratygrafia górnej jury w Czarnogłowach i Świętoszewie. Acta Geol. Pol. 1962, 12, 3-112.

56. Dmoch, I. Ślimaki i małże górnojurajskie Czarnogłowów i Świętoszewa oraz warunki paleookologiczne w jurze górnej na Pomorzu Zachodnim. Stud. Soc. Sci. Tor. 1970, 7, 1-113.

57. Hoffmann, N. Upper Jurassic Limestone Quarry of Czarnogłowy (Zarnglaff). In Geo-Pomerania Szczecin 2007: Geology CrossBordering the Western and Eastern European Platform. Excursion Guide; Niedermeyer, R.-O., Dobracki, R., Schütze, K., Eds.; Państwowy Instytut Geologiczny: Warszawa, Poland, 2007; pp. 44-47.

58. Maisey, J.G. Hamiltonichthys mapesi, g. \& sp. nov. (Chondrichthyes; Elasmobranchii), from the Upper Pennsylvanian of Kansas. Am. Mus. Novit. 1989, 2931,1-42.

59. Rees, J.; Underwood, C.J. Hybodont sharks of the English Bathonian and Callovian (Middle Jurassic). Palaeontology 2008, 51, 117-147. [CrossRef]

60. Huxley, T.H. On the application of the laws of evolution to the arrangement of the Vertebrata, and more particularly of the Mammalia. Proc. Zool. Soc. Lond. 1880, 649-662.

61. Bonaparte, C.L. Synopsis vertebratorum systematis. Nuovi Ann. Sci. Nat. Bologna 1838, 2, 105-133.

62. Maisey, J.G. The interrelationships of phalacanthous selachians. N. Jb. Geol. Paläontol. Mh. 1975, 553-567.

63. Owen, R. Lectures on the Comparative Anatomy and Physiology of the Vertebrate Animals, Delivered at the Royal College of Surgeons of England in 1844 and 1846; Part 1. Fishes; Longman: London, UK, 1846.

64. Maisey, J.G. Cranial anatomy of the Lower Jurassic shark Hybodus reticulatus (Chondrichthyes: Elasmobranchii), with comments on hybodontid systematics. Am. Mus. Novit. 1987, 2878, 1-39.

65. Rees, J. Early Jurassic selachians from the Hasle Formation on Bornholm, Denmark. Acta Palaeontol. Pol. 1998, 43, 439-452.

66. Maisch, M.W.; Matzke, A.T. A new hybodontid shark (Chondrichthyes, Hybodontiformes) from the Lower Jurassic Posidonienschiefer Formation of Dotternhausen, SW Germany. N. Jb. Geol. Paläontol. Abh. 2016, 280, 241-257. [CrossRef]

67. Agassiz, L.J.R. Recherches sur les Poissons Fossils; Petitpierre: Neuchâtel, Switzerland, 1833; Volume 5.

68. Underwood, C.J.; Cumbaa, S.L. Chondrichthyans from a Cenomanian (Late Cretaceous) bonebed, Saskatchewan, Canada. Palaeontology 2010, 53, 903-944. [CrossRef]

69. Rees, J.; Underwood, C.J. Hybodont sharks from the Middle Jurassic of the Inner Hebrides, Scotland. Trans. R. Soc. Edinb. Earth Sci. 2006, 96, 351-363. [CrossRef]

70. Bermúdez-Rochas, D.D. New hybodont shark assemblage from the Early Cretaceous of the Basque-Cantabrian Basin. Geobios 2009, 42, 675-686. [CrossRef]

71. Sharma, A.; Singh, S. A small assemblage of marine hybodont sharks from the Bathonian of the Jaisalmer Basin, India. N. Jb. Geol. Paläontol. Abh. 2021, 301, 317-333. [CrossRef] [PubMed]

72. Bourdon, J.; Wright, K.; Lucas, S.G.; Spielmann, J.A.; Pence, R. Selachians from the Upper Cretaceous (Santonian) Hosta Tongue of the Point Lookout Sandstone, central New Mexico. Bull. N. M. Mus. Nat. Hist. Sci. 2011, 52, 1-54. 
73. Woodward, A.S. The fossil fishes of the English Wealden and Purbeck formations. Monogr. Palaeontogr. Soc. Lond. 1916, 69, 1-48. [CrossRef]

74. Underwood, C.J.; Rees, J. Selachian faunas from the earliest Cretaceous Purbeck Group of Dorset, southern England. Pap. Palaeontol. 2002, 68, 83-101.

75. Duffin, C.J.; Sweetman, S.C. 17. Sharks. In English Wealden Fossils; Batten, D.J., Ed.; Field Guide to Fossils 11; Palaeontological Association: London, UK, 2011; pp. 205-224.

76. Turmine-Juhel, P.; Wilks, R.; Brockhurst, D.; Austen, P.A.; Duffin, C.J.; Benton, M.J. Microvertebrates from the Wadhurst Clay Formation (Lower Cretaceous) of Ashdown Brickworks, East Sussex, UK. Proc. Geol. Assoc. 2019, 130, 752-769. [CrossRef]

77. Pinheiro, F.L.; de Figueiredo, A.E.Q.; Dentzien-Dias, P.C.; Fortier, D.C.; Schultz, C.L.; Viana, M.S.S. Planohybodus marki sp. nov., a new fresh-water hybodontid shark from the Early Cretaceous of northeastern Brazil. Cret. Res. 2013, 41, 210-216. [CrossRef]

78. Rees, J. Jurassic and Early Cretaceous selachians-Focus on southern Scandinavia. Lund Publ. Geol. 2001, 153, 1-19.

79. Vullo, R. Direct evidence of hybodont shark predation on Late Jurassic ammonites. Naturwissenschaften 2011, 98, 545-549. [CrossRef] [PubMed]

80. Vullo, R.; Abit, D.; Ballèvre, M.; Billon-Bruyat, J.-P.; Bourgeais, R.; Buffetaut, E.; Daviero-Gomez, V.; Garcia, G.; Gomez, B.; Mazin, J.-M.; et al. Palaeontology of the Purbeck-type (Tithonian, Late Jurassic) bonebeds of Chassiron (Oléron Island, western France). Comptes Rendus Palevol 2014, 13, 421-441. [CrossRef]

81. Case, G.R. A new selachian fauna from the Coleraine Formation (Upper Cretaceous/Cenomanian) of Minnesota. Palaeontogr. Abt. A 2001, 261, 103-112.

82. Thurmond, J.T. Cartilaginous fishes of the Trinity Group and related rocks (Lower Cretaceous) of North Central Texas. Southeast. Geol. 1971, 13, 207-227.

83. Case, G.R. A new selachian fauna from the Judith River formation (Campanian) of Montana. Palaeontogr. Abt. A 1978, 160, 176-205.

84. Case, G.R.; Cappetta, H. Additions to the elasmobranch fauna from the late Cretaceous of New Jersey (lower Navesink Formation, early Maastrichtian). Palaeovertebrata 2004, 33, 1-16.

85. Cicimurri, D.J.; Ciampalgio, C.N.; Runyon, K.E. Late Cretaceous elasmobranchs from the Eutaw Formation at Luxapalila Creek, Lowndes County, Mississippi. PalArch's J. Vert. Palaeontol. 2014, 11, 1-36.

86. Jaekel, O. Die Selachier aus dem oberen Muschelkalk Lothringens. Abh. Geol. Spec. Els.-Lothr. 1889, 3, $275-340$.

87. Rees, J. Interrelationships of Mesozoic hybodont sharks as indicated by dental morphology-preliminary results. Acta Geol. Pol. 2008, 58, 217-221.

88. Egerton, P.M.G. On some new genera and species of fossil fishes. Ann. Mag. Nat. Hist. 1854, 13, 433-436. [CrossRef]

89. Sauvage, H.E. Notes sur les poissons fossils (suite). XVI-XXIII. Bull. Soc. Géol. Fr. 1880, 8, 451-462.

90. Stromer, E. Ergebnisse der Forschungsreisen Prof. E. Stromers in den Wüsten Ägyptens. II. Wirbeltier-Reste der BaharijeStufe (unterstes Cenoman). 9. Die Plagiostomen, mit einem Anhang über käno- und mesozoische Rückenflossenstacheln von Elasmobranchiern. Abh. Bayer. Akad. Wiss. Math.-Naturwiss. Kl. 1927, 31, 1-64.

91. Woodward, A.S. On some remains of the Extinct Selachian Asteracanthus from the Oxford Clay of Peterborough, preserved in the collection of Alfred, N. Leeds, Esq., of Eyebury. J. Nat. Hist. 1888, 2, 336-342. [CrossRef]

92. Szabó, M.; Főzy, I. Asteracanthus (Hybodontiformes: Acrodontidae) remains from the Jurassic of Hungary, with the description of a new species and with remarks on the taxonomy and paleobiology of the genus. N. Jb. Geol. Paläontol. Abh. 2020, 297, 295-309. [CrossRef]

93. Duffin, C.J. The dentition of Hybodus hauffianus Fraas, 1895 (Toarcian, Early Jurassic). Stuttg. Beitr. Naturkd. B 1997, 256, 1-20.

94. Maisey, J.G. Cranial antomy of Hybodus basanus Egerton from the Lower Cretaceous of England. Am. Mus. Novit. 1983, 2758, 1-26.

95. Dunker, W. Ueber einen neuen Asteracanthus aus dem Korallenkalk des Lindner Berges bei Hannover. Palaeontographica 1851, 1 , 188-189.

96. Dunker, W. Asteracanthus ornatissimus, Agassiz, aus dem Korallenkalk von Hoheneggelsen bei Hildesheim. Palaeontographica 1851, 1,316-318

97. Platnauer, H.M. Note on Hybodus obtusus. Ann. Rep. Yorks. Phil. Soc. 1887, 35-36.

98. Priem, F. Etude des poissons fossiles du Bassin Parisien (supplément). Ann. Paléontol. 1911, 6, 1-144.

99. Casier, E. Contributions a l'etude des Poissons fossils de la Belgique. XII. Selaciens et Holocephales sinemuriens de la province de Luxembourg. Bull. Inst. R. Sci. Nat. Bel. 1959, 35, 1-27.

100. Rieppel, O. The hybodontiform sharks from the Middle Triassic of Mte. San Giorgio, Switzerland. N. Jb. Geol. Paläontol. Abh. 1981, 16, 324-353.

101. Goto, M. Palaeozoic and early Mesozoic fish faunas of the Japanese Islands. Isl. Arc. 1994, 3, 247-254. [CrossRef]

102. Cuny, G.; Srisuk, P.; Khamha, S.; Suteethorn, V.; Tong, H. A new elasmobranch fauna from the Middle Jurassic of southern Thailand. In Late Palaeozoic and Mesozoic Ecosystems in SE Asia; Buffetaut, E., Cuny, G., Le Loeuff, J., Suteethorn, V., Eds.; Special Publications 315; The Geological Society: London, UK, 2009; pp. 97-113. [CrossRef]

103. Guinot, G.; Cappetta, H.; Adnet, S. A rare elasmobranch assemblage from the Valanginian (Lower Cretaceous) of southern France. Cret. Res. 2014, 48, 54-84. [CrossRef] 
104. Vincent, P.; Martin, J.E.; Fischer, V.; Suan, G.; Khalloufi, B.; Suchéras-Marx, B.; Lena, A.; Janneau, K.; Rousselle, B.; Rulleau, L. Marine vertebrate remains from the Toarcian-Aalenian succession of southern Beaujolais, Rhône, France. Geol. Mag. 2013, 150, 822-834. [CrossRef]

105. Citton, P.; Fabbi, S.; Cipriani, A.; Jansen, M.; Romano, M. Hybodont dentition from the Upper Jurassic of Monte Nerone Pelagic Carbonate Platform (Umbria-Marche Apennine, Italy) and its ecological implications. Geol. J. 2019, 54, 278-290. [CrossRef]

106. Peyer, B. Die schweizerischen Funde von Asteracanthus (Strophodus). Schweiz. Palaeontol. Abh. 1946, 64, 1-101.

107. Rigal, S.; Cuny, G. On the rarity of anterior teeth of Asteracanthus magnus (Euselachii: Hybodontiformes). N. Jb. Geol. Paläontol. Abh. 2016, 279, 35-41. [CrossRef]

108. Kumar, K.; Bajpai, S.; Pandey, P.; Ghosh, T.; Bhattacharya, D. Hybodont sharks from the Jurassic of Jaisalmer, western India. Hist. Biol. 2021. [CrossRef]

109. Owen, R. Description of a great part of a jaw with the teeth of Strophodus medius, Ow., from the Oolite of Caen in Normandy. Geol. Mag. 1869, 6, 193-196. [CrossRef]

110. Martill, D.M. Fossils of the Oxford Clay; Martill, D.M., Hudson, J.D., Eds.; Field Guide to Fossils 4; Palaeontological Association: London, UK, 1991; pp. 197-225.

111. Pfeil, F.H. Ein neues Asteracanthus-Gebiss aus den Kieselplattenkalken (Oberjura, Tithonium, Malm Zeta 3, Mörnsheim-Formation) des Besuchersteinbruchs in Mühlheim. Fr. Bayer; Staatssammlung für Paläontologie und Historische Geologie München: München, Germany, 2011; Volume 39, pp. 36-60.

112. Münster, G.V. Beschreibung einiger neuer Fische aus den lithographischen Schiefern von Bayern. Beitr. Petrefactenkd. 1842, 5, 55-64.

113. Wagner, J.A. Charakteristik neuer Arten von Knorpelfischen aus den lithographischen Schiefern der Umgegend von Solnhofen. Gelehrte Anz. Königl. Bayer. Akad. Wiss. 1857, 44, 288-293.

114. Kriwet, J.; Klug, S. Diversity and biogeography patterns of Late Jurassic neoselachians (Chondrichthyes: Elasmobranchii). In Fishes and the Break-Up of Pangaea; Cavin, L., Longbottom, A., Richter, M., Eds.; Special Publications 295; The Geological Society: London, UK, 2008; pp. 55-70. [CrossRef]

115. Leuzinger, L.; Kocsis, L.; Billon-Bruyat, J.-P.; Spezzaferri, S.; Vennemann, T. Stable isotope study of a new chondrichthyan fauna (Kimmeridgian, Porrentruy, Swiss Jura): An unusual freshwater-influenced isotopic composition for the hybodont shark Asteracanthus. Biogeosciences 2015, 12, 6945-6954. [CrossRef]

116. Maisey, J.G. The anatomy and interrelationships of Mesozoic hybodont sharks. Am. Mus. Novit. 1982, $2724,1-48$.

117. Soler-Gijón, R.; Poyato-Ariza, F.J.; Maisey, J.G.; Lane, J.A. Chondrichthyes. In Las Hoyas: A Cretaceous Wetland; Poyato-Ariza, F.J., Buscalioni, A.D., Fregenal-Martinez, M., Eds.; Verlag Dr. Friedrich Pfeil: München, Germany, 2016; pp. 103-113.

118. Duffin, C.J. 16. Fishes-Sharks and rays. In Fossils from the Lower Lias of the Dorset Coast; Lord, A.R., Davis, P.G., Eds.; Field Guide to Fossils 13; Palaeontological Association: London, UK, 2010; pp. 317-340.

119. Stumpf, S.; Kriwet, J. A new Pliensbachian elasmobranch (Vertebrata, Chondrichthyes) assemblage from Europe, and its contribution to the understanding of late Early Jurassic elasmobranch diversity and distributional patterns. PalZ 2019, 93, 637-658. [CrossRef]

120. Smith, A.G.; Smith, D.G.; Funnell, B.M. Atlas of Mesozoic and Cenozoic Coastlines; Cambridge University Press: Cambridge, London, 2004; p. 112.

121. Lott, G.K.; Wong, T.E.; Dusar, M.; Andsbjerg, J.; Mönnig, E.; Feldman-Olszewska, A.; Verreussel, R.M.C.H. Jurassic. In Petroleum Geological Atlas of the Southern Permian Basin Area; Doornenbal, J.C., Stevenson, A.G., Eds.; EAGE Publications B.V.: Houten, The Netherlands, 2010; pp. 175-193.

122. Madzia, D.; Szczygielski, T.; Wolniewicz, A.S. The giant pliosaurid that wasn't-revising the marine reptiles from the Kimmeridgian, Upper Jurassic, of Krzyżanowice, Poland. Acta Palaeontol. Pol. 2021, 66, 99-129. [CrossRef]

123. Rees, J.; Underwood, C.J. The status of the shark genus Lissodus, and the position of nominal Lissodus species within the Hybodontoidea. J. Vert. Paleontol. 2002, 22, 471-479. [CrossRef]

124. Underwood, C.J. Diversification of the Neoselachii (Chondrichthyes) during the Jurassic and Cretaceous. Paleobiology 2006, 32, 215-235. [CrossRef]

125. Kriwet, J.; Kiessling, W.; Klug, S. Diversification trajectories and evolutionary life-history traits in early sharks and batoids. Proc. R. Soc. B 2009, 276, 945-951. [CrossRef]

126. Rees, J.; Cuny, G.; Pouech, J.; Mazin, J.-M. Non-marine selachians from the basal Cretaceous of Charente, SW France. Cret. Res. 2013, 44, 122-131. [CrossRef]

127. Klug, C.; Schweigert, G.; Hoffmann, R.; Weis, R.; De Baets, K. Fossilized leftover falls as sources of palaeoecological data: A 'pabulite' comprising a crustacean, a belemnite and a vertebrate from the Early Jurassic Posidonia Shale. Swiss J. Palaeontol. 2021, 140, 10. [CrossRef] [PubMed] 